\title{
Mėsinių bulių veislių įtaka Lietuvos juodmargių mėsos produkcijai ir kokybei
}

\section{Audrius Korsukovas, \\ Česlovas Jukna, \\ Vaidotas Prusevičius}

Lietuvos sveikatos mokslu universitetas, Veterinarijos akademija,

A. Mickevičiaus g. 9, LT-44307 Kaunas

El.paštasaudriuskorsukovas@gmail.com
Straipsnyje skelbiami duomenys apie skirtingų mèsinių veislių bulių įtaką Lietuvos juodmargių augimo spartai, pašarų sąnaudoms, lemiančioms priesvori, skerdenos išeigai, kokybei, morfologinei sudečiai bei mėsos fizinėms savybėms ir cheminiai sudèčiai. Sudarytos kontrolinės grynaveisliu Lietuvos juodmargiụ (LJ) ir Lietuvos juodmargių mišrūnų buliukų grupès: Lietuvos juodmargiu $\times$ limuzinų $(\mathrm{LJ} \times \mathrm{LI})$, Lietuvos juodmargiu $\times$ simen-

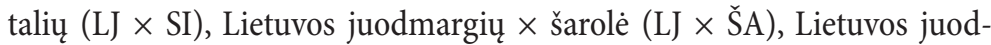
margiu $\times$ angusų $(\mathrm{LJ} \times \mathrm{AN})$, Lietuvos juodmargių $\times$ aubrakų $(\mathrm{LJ} \times \mathrm{AU})$. Kiekvienoje grupèje buvo 18-20 buliukų. Grupes sudarė dviejų bulių palikuonys. Tyrimai atlikti su 120-500 dienų amžiaus buliukais.

Raktažodžiai: Lietuvos juodmargiai, skerdenos išeiga, mėsos kokybe், pašarų sąnaudos

\section{IVADAS}

Lietuvoje mèsinè galvijininkystė yra jauniausia žemès ūkio šaka, todèl didžioji dalis galvijų mèsos gaunama iš pieninių veislių ir iš jų mišrūnų su mèsinèmis veislëmis. Todèl svarbu žinoti, kokie kryžminimo deriniai palankiausi. Gyvulio priešskerdiminè masé, priesvoris per parą, pašarų sąnaudos priesvorio vienetui, skerdenos išeiga yra itin svarbūs ekonominiai rodikliai augintojui, kiti požymiai, kaip skerdenos morfologinè sudetis, mèsos fizinès savybès ir jos cheminè sudètis, yra reikšmingi mèsos perdirbejjams ir vartotojams (Jukna ir kt., 2006; 2009). Galvijienos gamyboje didelę reikšmę turi veislè. Taip pat labai svarbus vaidmuo tenka buliams, turintiems didelę itaką gaunamos galvijienos kiekybiniams ir kokybiniams rodikliams (Renand et al., 2001; Ozluturk et al., 2004; Wajda et al., 2006). Gyvulių produktyvumas ir produkcijos kokybė priklauso nuo neatskiriamų genotipinių ir aplinkos veiksnių. Gerindami gyvulių genotipą turime sudaryti ir tinkamas sąlygas jam realizuoti. Kryžminimo sèkmé galvijininkysteje priklauso nuo veislių suderinamumo ir mišrū- nų šèrimo bei laikymo sąlygų (Jukna ir kt., 1998; Gao et al., 2007). Rinkoje didejjanti konkurencija ir kylantys reikalavimai mėsos kokybei verčia ieškoti sprendimų, kaip turimų pieninių veislių galvijų pagrindu padidinti galvijienos gamybos efektyvumą ir pagerinti jos kokybę. Mèsos gamybos konkurencingumas, paklausa ir dominavimas rinkoje priklauso nuo mèsos kokybès bei prekinès išvaizdos. Didžiausią paklausą turi mèsa, pasižyminti geromis juslinèmis, skoninèmis, technologinèmis ir kulinarinèmis savybèmis. Mèsos maistingumas, energetinè verte ir kai kurios juslinès savybès priklauso nuo raumenų, tarpraumeniniu riebalų ir jungiamojo audinio santykio bei šių audinių cheminès sudèties, t. y. baltymų, tarpraumeninių riebalų, angliavandenių, mikro- ir makroelementų kiekio joje (Stankevičius ir kt., 2001; Jukna ir kt., 2003).

Atliktų mokslinių tyrimų autorių duomenimis, kryžminant juodmarges karves su limuzinų ir šarolè buliukais (Shchukina, 2008) gauti šarolè mišrūnai svèrè $30 \%$, o limuzinų mišrūnai $16 \%$ daugiau nei grynaveisliai juodmargių buliukai. Kryžminant juodmarges karves su šarolè, limuzinų, angusų 
veislès buliais (Babarinov ir kt., 2001; Gnezdilova ir kt., 2006; Sudarev ir kt., 2008), visų gautų veislių mišrūnų paros priesvoriai buvo didesni nei grynaveislių juodmargių buliukų. Kad gautų mišrūnų didesnè skerdenos išeiga, skerdena būna mèsingesnè, yra nustatę ir kiti autoriai (Kosilov ir kt., 2004; Zelenov ir kt., 2006).

Lietuvoje atlikta nemažai tyrimų kryžminant Lietuvos juodmarges karves su įvairių mèsinių veislių buliais. Tačiau tai buvo pavieniai tyrimai. Duomenų apie Lietuvos juodmargių kryžminimą su ịvairių mėsinių veislių buliais auginant mišrūnus vienodomis sąlygomis nebuvo. Tokie duomenys labai reikalingi gyvulių augintojams pasirenkant veisles kryžminimui.

Darbo tikslas - ištirti skirtingo genotipo buliukų augimo spartą, pašarų sąnaudas priesvoriui, skerdenos išeigą ir kokybę, morfologinę sudèti bei mèsos fizines savybes ir cheminę sudètį.

\section{MEDŽIAGOS IR METODAI}

Tyrimams buvo sudarytos 6 grupès: kontrolinè Lietuvos juodmargių (LJ), Lietuvos juodmargių $\times$ limuzinų $(\mathrm{LJ} \times \mathrm{LI})$, Lietuvos juodmargių $\times$ simentalių $(\mathrm{LJ} \times \mathrm{SI})$, Lietuvos juodmargių $\times$ šarole $(\mathrm{LJ} \times$ ŠA), Lietuvos juodmargių $\times$ angusu $(\mathrm{LJ} \times \mathrm{AN})$, Lietuvos juodmargiu $\times$ aubraku $(\mathrm{LJ} \times \mathrm{AU})$. Kiekvienoje grupeje buvo 18-20 buliukų. Grupes sudarè dviejų bulių palikuonys. Tyrimai atlikti su 120-500 dienų amžiaus buliukais. Buliukai buvo laikomi pririšti, nekastruoti. Bandymo laikotarpiu vykdyta tiksli suėstų pašarų apskaita. Žolinių pašarų gyvuliai gavo iki soties, o kombinuotujuc - po $1 \mathrm{~kg} 100 \mathrm{~kg}$ gyvulio masès. Suèstų žolinių pašarų kiekis buvo nustatomas atliekant kontrolinius įdedamo pašaro ir nesuèstų pašarų likučių svėrimus vieną kartą per 2 savaites 2 dienas iš eilès. Buliukai buvo sveriami kartą per du ménesius, o sulaukę 12 mèn. - kartą per ménesị.

Pasiekus 500 dienų amžių iš kiekvienos grupès atrinkta po 8 labiausiai atitinkančius vidurkị gyvulius kontroliniam skerdimui, klubo-šlaunies dalies morfologinei sudèčiai nustatyti. Kontrolinis skerdimas atliktas po 24 valandu alkinimo. Vandens buvo neduodama likus 3 val. iki skerdimo. Kontrolinio skerdimo metu sveriant gyvuli buvo nustatoma gyvulio masè po 24 valandų alkinimo, šiltos skerdenos masé ịvertinta sveriant, raumeningumo ir riebalingumo klasės nustatytos skerdenu vertintojo, kairès puselès klubo-šlaunies dalies masė ir minkštųjų dalių masẻ sveriant, taip pat ir kaulų masè. Apskaičiuota minkštųjų dalių išeiga proc., klubo-šlaunies dalies išeiga proc.

Mèsos kokybei įvertinti buvo paimtas bandinys iš ilgiausiojo nugaros raumens (musculus longissimus dorsi) ties 9-11 šonkauliais. Nustatoma raumens cheminè sudètis ir fizinès-cheminès savybès. Sausosios medžiagos buvo ịvertintos mèsos mėginius džiovinant iki pastovios masès automatinèmis sausųjų medžiagų svarstyklèmis (Stimbirys ir kt., 2010), baltymų kiekis - Kjeldalio metodu (Kjeldahl, 1883), riebalų kiekis - Soksleto metodu naudojant Soxtern SE 416 macro (ISO 1443:1973; Meat and meat products determination of total fat content), pelenai - sudeginant mèsos organinę medžiagą $600-800{ }^{\circ} \mathrm{C}$ temperatūroje (ISO 936:1998; Meat and meat products determination of total ash), mèsos kietumas - Warner-Bratzler metodu (Stimbirys ir kt., 2010), vandens rišlumas - Grau ir Hammo metodu (Grau, Ham, 1956; Daszkiewich et al., 2005), pH matuotas naudojant Inolab-3 pH-metrą (ISO 2917:1999; Meat and meat products measurement of $p H$ ), spalvingumas - Minolta Chroma Meter 410 pagal CIE-LAB metodą, matuojant mésos šviesumą $\left(\mathrm{L}^{*}\right)$, rausvumą $\left(\mathrm{a}^{*}\right)$ ir gelsvumą $\left(b^{*}\right)$ (Van Oeckel et al., 1999), virimo nuostoliai nustatyti mėsą verdant cirkuliacineje vandens vonelèje $30 \mathrm{~min}$., pagal mėginio masės pokyčius prieš verdant ir išvirus, vandeningumas pagal mėginio masès sumažéjimą per 24 val. laikant mèsą pakabintą specialiuose tinkliniuose maišeliuose $+4{ }^{\circ} \mathrm{C}$ temperatūroje (Van Oeckel et al., 1999; Daszkiewicz et al., 2005; Stimbirys ir kt., 2010).

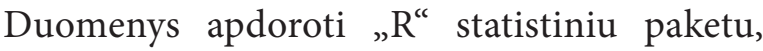
versija 2.0.1. Taip pat statistinei analizei naudoti skaičiuoklès „Exel“ duomenų analizès įrankiai. Genetinių veiksnių įtaka (procentais) skaičiuota dispersinès analizès (ANOVA) metodu. Nustatytas koreliacijos koeficientas $(r)$. Rezultatai laikyti patikimais, kai $p<0,05$.

Tyrimų rezultatai ir jų aptarimas. Bandymai parodè, kad skirtingų veislių mišrūnų 500 dienų amžiaus buliukų masẻ buvo nevienoda (1 pav.). Daugiausia svėré LJ $\times$ ŠA buliukai. Jų masè siekè $53 \mathrm{~kg}$, arba 10,8\% didesnè nei grynaveisliu LJ bendraamžių $(p<0,001)$. Analogiški rezultatai 


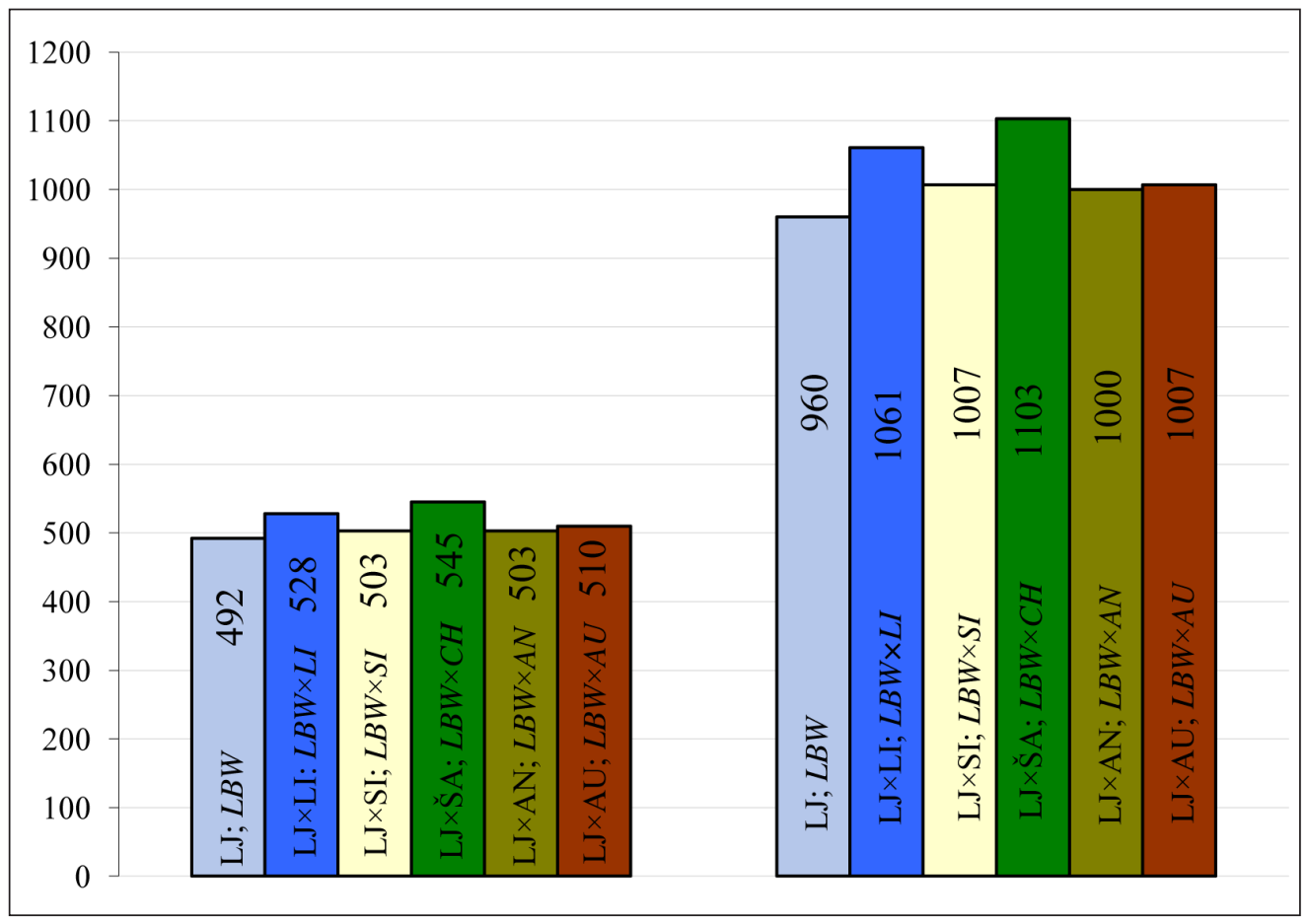

1 pav. Priesvoris per kontrolinị auginimą (g) ir 500 dienų amžiaus masè kg

Fig. 1. The overweight during the control breeding period, $\mathrm{g}$, and the mass of 500 days old, $\mathrm{kg}$

gauti ir užsienio autorių. Kryžminant juodmarges karves su limuzinu ir šarolè buliukais (Shchukina, 2008) gauti šarolè mišrūnai svèrè $30 \%$, o limuzinų mišrūnai $16 \%$ daugiau nei grynaveisliai juodmargių buliukai. Skirtingų veislių mišrūnų priesvoriai per kontrolini auginimą buvo skirtingi (1 pav.). Didžiausiu priesvoriu per parą pasižymejjo LJ $\times$ ŠA buliukai. Jų priesvoris per parą buvo $143 \mathrm{~g}$, arba $14,9 \%$ didesnis nei grynaveislių LJ buliukų $(p<0,001)$. Kitų veislių mišrūnų priesvoriai per parą irgi buvo didesni nei kontrolinès LJ grupès buliukų, tačiau skirtumas buvo mažesnis: LJ $\times$ LI mišrūnai $101 \mathrm{~g}$, arba $10,5 \%(p<0,001), \mathrm{LJ} \times \mathrm{AU}$ ir LJ $\times$ SI $47 \mathrm{~g}$, arba $4,9 \%(p<0,05-p<0,01), \mathrm{LJ} \times \mathrm{AN} 40 \mathrm{~g}$, arba $4,1 \%$ $(p<0,05)$ didesni negu grynaveislių LJ buliukų. Kryžminant juodmarges karves su šarole, limuzinų, angusų veislès buliais (Babarinov ir kt., 2001; Sudariov ir kt., 2005; Gnezdilova ir kt., 2006) visų gautų veislių mišrūnų paros priesvoriai buvo didesni nei grynaveislių juodmargių buliukų.

Skirtingų veislių mišrūnų buliukų pašarų sąnaudos $1 \mathrm{~kg}$ priesvorio MJ/AE buvo nevienodos (2 pav.). Mažiausios - LJ $\times$ ŠA mišrūnų buliukų, siekè 6,5 MJ/AE, arba 8,4 \% mažesnès nei grynaveislių $L J$ buliukų. Kitų veislių mišrūnų pašarų sąnaudos $1 \mathrm{~kg}$ priesvorio $\mathrm{MJ} / \mathrm{AE}$ taip pat buvo ma- žesnès, tačiau skirtumas ne toks didelis, $\mathrm{LJ} \times \mathrm{LI}$ ir $\mathrm{LJ} \times \mathrm{AU} 4,4 \mathrm{MJ} / \mathrm{AE}$, arba 5,6 \%, LJ $\times$ SI 2,4 MJ/

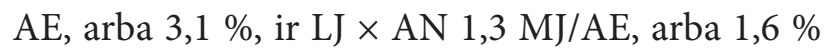
mažiau nei kontrolinès grynaveisliu LJ buliukų. K. T. Ekombetovo ir kt. (2005) bandymų duomenimis, visų tirtujų veislių mišrūnų pašarų sąnaudos priesvorio vienetui buvo mažesnès negu grynaveislių.

Genotipo itaka buliuku skerdenos kiekybiniams rodikliams (1 lentelè) parodè, kad visų veislių mišrūnų buliukų skerdenos masè buvo nevienoda. Didžiausia - LJ $\times$ ŠA buliukų siekè $51,5 \mathrm{~kg}$, arba 19,0\% $(p<0,001), \mathrm{LJ} \times$ LI mišrūnų - 35,8 kg, arba 13,2\% $(p<0,01)$ didesnè nei grynaveislių LJ buliukų. Bandymai parode, kad visų veislių mišrūnų buliukų skerdenos išeiga buvo didesnè nei kontrolinès LJ grupès. Didžiausia skerdenos išeiga $-\mathrm{LJ} \times$ SI buliukų $-5,4 \%$ didesnė nei grynaveislių LJ buliukų $(p<0,001)$. Kitu veislių mišrūnų grupių: LJ $\times$ LI 5,4 \% $(p<0,001)$, $\mathrm{LJ} \times \mathrm{AU} 3,7 \%(p<0,001), \mathrm{LJ} \times \check{\mathrm{S} A} 3,2 \%(p<0,01)$ ir LJ $\times$ AN 3,5 \% $(p<0,05)$ didesnè nei kontroliniu grynaveislių LJ buliukų. Apie gautų mišrūnų didesnę skerdenos išeigą, mèsingumą yra rašę ir kiti autoriai (Kosilov ir kt., 2004; Zelenov ir kt., 2006). Visų veislių mišrūnų buliukų skerdenos buvo aukštesnès raumeningumo kategorijos ir svyravo 


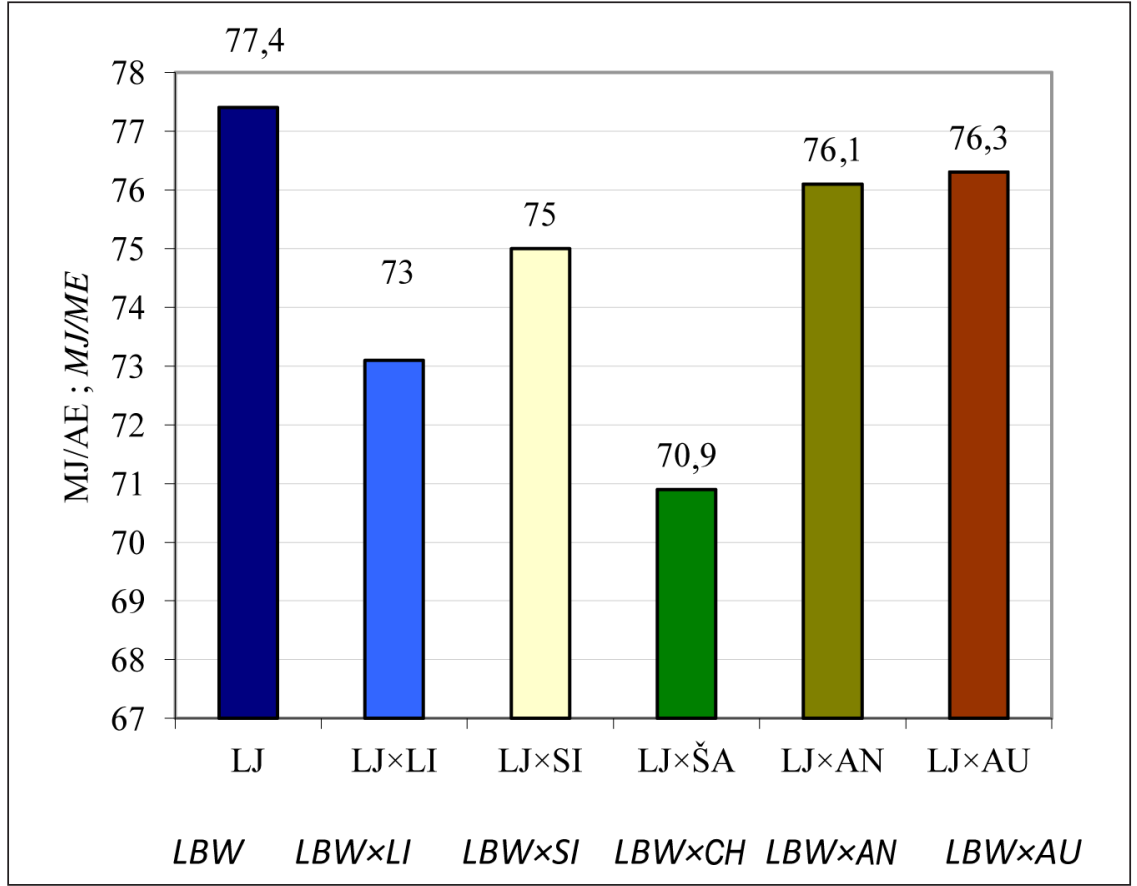

2 pav. Pašarų sąnaudos $1 \mathrm{~kg}$ priesvorio $\mathrm{MJ} / \mathrm{AE}$

Fig. 2. Forage input for $1 \mathrm{~kg}$ overweight, $M J / M E$

tarp U/R kategorijų, o kontrolinès grynaveislių LJ buliukų raumeningumas - O kategorijos. Skerdenos riebalingumo kategorijos buvo panašios.

Bandymai parodè (2 lentelè), kad klubo-šlaunies dalies masė $\mathrm{LJ} \times$ ŠA mišrūnų buliukų buvo $10,2 \mathrm{~kg}$, arba $24,2 \%(p<0,001), \mathrm{LJ} \times \mathrm{LI} 8,8 \mathrm{~kg}$, arba $20,9 \%(p<0,001)$ didesnè negu kontrolinių LJ.
Didžiausia klubo-šlaunies dalies išeiga pasižymėjo LJ $\times$ LI mišrūnai, ji buvo 2,1 \% didesnè negu gry-

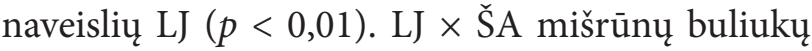
klubo-šlaunies dalies išeiga buvo 1,5 \% ir $\mathrm{LJ} \times \mathrm{AU}$ $1,0 \%$ didesnè nei kontrolinès grynaveislių LJ buliukų $(p<0,05)$. Didžiausia kaulų mase $\mathrm{LJ} \times \mathrm{AU}$ mišrūnų buliukų - 1,5 kg, arba 17,44 \% $(p<0,01)$,

1 lentelè. Genotipo įtaka skerdenos kiekybiniams rodikliams

Table 1. The influence of genotype on quantitative indicators of carcas

\begin{tabular}{|c|c|c|c|c|c|}
\hline $\begin{array}{l}\text { Veislè } \\
\text { Breed }\end{array}$ & $\begin{array}{l}\text { Priešskerdiminė } \\
\text { gyvulio masė kg } \\
\text { Animal mass be- } \\
\text { fore slaughter, } k g\end{array}$ & $\begin{array}{l}\text { Skerdenos } \\
\text { masè kg } \\
\text { Carcass mass, } \\
\text { kg }\end{array}$ & $\begin{array}{c}\text { Skerdenos } \\
\text { išeiga \% } \\
\text { Carcass yield, } \\
\%\end{array}$ & $\begin{array}{l}\text { Skerdenos raumenin- } \\
\text { gumo kategorija } \\
\text { Category of carcass } \\
\text { muscularity }\end{array}$ & $\begin{array}{c}\text { Skerdenos rieba- } \\
\text { lingumo kategorija } \\
\text { Category of carcass } \\
\text { fatness }\end{array}$ \\
\hline $\begin{array}{c}\mathrm{LJ} \\
L B W\end{array}$ & $549,3 \pm 8,97$ & $270,9 \pm 4,41$ & $49,3 \pm 0,43$ & $\mathrm{O}$ & 3 \\
\hline $\begin{array}{c}\mathrm{LJ} \times \mathrm{LI} \\
L B W \times L I\end{array}$ & $570 \pm 12,54$ & $306,7 \pm 7,65^{\star *}$ & $53,8 \pm 0,63^{\star * *}$ & $\mathrm{R}$ & $2 / 3$ \\
\hline $\begin{array}{c}\mathrm{LJ} \times \mathrm{SI} \\
L B W \times S I\end{array}$ & $532,5 \pm 3,23$ & $291,6 \pm 9,79$ & $54,7 \pm 1,59^{* * *}$ & $\mathrm{R}$ & $2 / 3$ \\
\hline $\begin{array}{c}\mathrm{LJ} \times \check{\mathrm{S}} \mathrm{A} \\
L B W \times C H\end{array}$ & $613,1 \pm 13,06^{\star *}$ & $322,4 \pm 9,76^{* * *}$ & $52,5 \pm 0,64^{\star *}$ & $\mathrm{U} / \mathrm{R}$ & $2 / 3$ \\
\hline $\begin{array}{c}\mathrm{LJ} \mathrm{AN} \\
L B W \times A N\end{array}$ & $550,0 \pm 10,21$ & $290,4 \pm 10,56$ & $52,8 \pm 1,34^{*}$ & $\mathrm{R}$ & 3 \\
\hline $\begin{array}{c}\mathrm{LJ} \times \mathrm{AU} \\
L B W \times A U\end{array}$ & $555,4 \pm 11,18$ & $294,3 \pm 6,51^{\star}$ & $53,0 \pm 0,82^{\star \star}$ & $\mathrm{R}$ & 3 \\
\hline
\end{tabular}

Pastaba / Note: ${ }^{\star}-p<0,05 ;{ }^{* *}-p<0,01{ }^{* * *}-p<0,001$ (LJ - kontrolinè grupe / control group). 
2 lentelè. Genotipo įtaka skerdenos klubo-šlaunies dalies morfologinei sudèčiai

Table 2. The influence of genotype on morphological composition of hock-femoral

\begin{tabular}{|c|c|c|c|c|c|}
\hline $\begin{array}{l}\text { Veislè } \\
\text { Breed }\end{array}$ & $\begin{array}{l}\text { Masė kg } \\
\text { Mass, } \mathrm{kg}\end{array}$ & $\begin{array}{l}\text { Išeiga \% } \\
\text { Yield, \% }\end{array}$ & $\begin{array}{l}\text { Kaulų masė kg } \\
\text { Bone mass, } \mathrm{kg}\end{array}$ & $\begin{array}{l}\text { Minkštujų dalių masẻ kg } \\
\text { Soft tissue mass, } \mathrm{kg}\end{array}$ & $\begin{array}{c}\text { Minkštụjų dalių išeiga \% } \\
\text { Soft tisue yield, \% }\end{array}$ \\
\hline$\stackrel{\mathrm{LJ}}{L B W}$ & $42,1 \pm 0,79$ & $31,1 \pm 0,66$ & $8,6 \pm 0,44$ & $33,6 \pm 0,59$ & $79,6 \pm 0,82$ \\
\hline $\begin{array}{c}\mathrm{LJ} \times \mathrm{LI} \\
L B W \times L I\end{array}$ & $50,9 \pm 1,26^{* * *}$ & $33,2 \pm 0,33^{* *}$ & $9,2 \pm 0,31$ & $41,6 \pm 1,16^{* * *}$ & $81,9 \pm 0,61^{\star}$ \\
\hline $\begin{array}{c}\mathrm{LJ} \times \mathrm{SI} \\
L B W \times S I\end{array}$ & $42,9 \pm 2,22$ & $29,5 \pm 1,67$ & $7,6 \pm 0,39$ & $34,7 \pm 1,73$ & $82,3 \pm 0,55^{\star}$ \\
\hline $\begin{array}{c}\mathrm{LJ} \times \check{\mathrm{S} A} \\
L B W \times C H\end{array}$ & $52,3 \pm 1,12^{* * *}$ & $32,6 \pm 0,6^{*}$ & $9,8 \pm 0,22^{*}$ & $42,2 \pm 1,05^{\star * *}$ & $81,2 \pm 0,45$ \\
\hline $\begin{array}{c}\mathrm{LJ} \times \mathrm{AN} \\
L B W \times A N\end{array}$ & $44,5 \pm 2,21$ & $30,6 \pm 0,71$ & $8,3 \pm 0,28$ & $38,4 \pm 0,54^{* *}$ & $81,2 \pm 1,68$ \\
\hline $\begin{array}{c}\mathrm{LJ} \times \mathrm{AU} \\
L B W \times A U\end{array}$ & $47,0 \pm 1,68$ & $32,1 \pm 0,58^{\star}$ & $10,1 \pm 0,38^{\star *}$ & $36,9 \pm 1,45^{\star}$ & $78,4 \pm 0,52$ \\
\hline
\end{tabular}

Pastaba / Note: ${ }^{*}-p<0,05 ;^{* *}-p<0,01 ;^{* * *}-p<0,001$ (LJ - kontrolinė grupé / control group).

o LJ × ŠA mišrūnų - 1,2 kg, arba 13,95\% $(p<0,05)$ didesnè nei kontrolinès LJ buliukų. Minkštųjų dalių masè skirtingu veisliu mišrūnu buliuku buvo nevienoda. Didžiausia LJ × ŠA mišrūnų buliukų - 8,6 kg, arba 25,59\% $(p<0,001)$ didesnè nei kontrolinès grupès. Kitų veislių mišrūnų buliukų minkštųjų dalių masè irgi buvo didesnè nei kontrolinès LJ grupès buliukų, tačiau skirtumai buvo mažesni: $\mathrm{LJ} \times \mathrm{LI}$ $8,0 \mathrm{~kg}$, arba $23,80 \%(p<0,001), \mathrm{LJ} \times \mathrm{AN} \mathrm{4,8} \mathrm{kg}$, arba 14,28\% $(p<0,01)$ ir LJ $\times$ AU 3,3 kg, arba 9,8\% $(p<0,05)$ didesnè nei grynaveislių LJ buliukų.

Grynaveislių LJ buliukų mèsos $\mathrm{pH}$ buvo aukščiausias (3 lentelè), LJ $\times$ SI mišrūnų buliuku - kaip ir kontrolinès LJ buliukų. LJ $\times$ LI mišrūnų buliukų mésos $\mathrm{pH}-0,6$ žemesnè negu kontrolinès grynaveislių LJ buliukų mėsos. Visų tirtųjų buliukų grupių mėsos $\mathrm{pH}$ skirtumai buvo statistiškai nepatikimi.
Šviesiausia mèsa pasižymejo LJ $\times$ AU mišrūnų buliukai. Ji buvo 4,91 vieneto šviesesnè, arba $14,1 \%(p<0,001)$, o LJ $\times$ LI mišrūnų buliukų 3,9 vieneto, arba $11,2 \%(p<0,01)$ nei kontrolinès grynaveislių LJ buliukų mėsa. Mèsos rausvumu labiausiai pasižymėjo $\mathrm{LJ} \times \mathrm{AU}$ mišrūnų buliukų mèsa - 2,32 vieneto rausvesnè. Visų tirtujų veislių mišrūnų buliukų grupių duomenų skirtumai, apibūdinantys mėsos rausvumą, buvo statistiškai nepatikimi. Mėsos gelsvumu labiausiai pasižymèjo LJ $\times$ LI mišrūnų buliukų mėsa, ji buvo 2,44 vieneto, arba $47,37 \%(p<0,01)$, o LJ $\times$ AU mišrūnų buliukų mèsa - 1,5 vieneto, arba 29,12\% $(p<0,05)$ gelsvesnè nei kontrolinės grynaveislių LJ.

Genotipo ịtaka mėsos vandeningumui, vandens rišlumui, virimo nuostoliams ir kietumui parode (4 lentelè), kad mésos vandeningumu labiausiai

3 lentelè. Genotipo ịtaka mèsos rūgštingumui ir spalvingumui

Table 3. The influence of genotype on meat acidity and colour

\begin{tabular}{|c|c|c|c|c|}
\hline \multirow{2}{*}{$\begin{array}{l}\text { Veislè } \\
\text { Breed }\end{array}$} & \multirow{2}{*}{$\mathrm{pH}$} & \multicolumn{3}{|c|}{ Spalvingumas / Colour } \\
\hline & & $\mathbf{L}^{*}$ & $a^{*}$ & $\mathbf{b}^{*}$ \\
\hline $\mathbf{L J} / \boldsymbol{L B W}$ & $6,43 \pm 0,16$ & $34,73 \pm 0,95$ & $17,85 \pm 0,83$ & $5,15 \pm 0,53$ \\
\hline $\mathrm{Lj} \times \mathrm{LI} / L B W \times L I$ & $5,83 \pm 0,19$ & $38,63 \pm 1,13 * *$ & $19,98 \pm 0,63$ & $7,59 \pm 0,39 * *$ \\
\hline $\mathrm{Lj} \times \mathrm{SI} / L B W \times S I$ & $6,44 \pm 0,34$ & $35,33 \pm 1,76$ & $16,09 \pm 0,96$ & $5,58 \pm 0,46$ \\
\hline $\mathrm{Lj} \times \check{\mathrm{S}} \mathrm{A} / L B W \times C H$ & $6,3 \pm 0,18$ & $35,56 \pm 1,2$ & $18,59 \pm 1,27$ & $5,99 \pm 1,04$ \\
\hline $\mathrm{Lj} \times \mathrm{AN} / L B W \times A N$ & $6,15 \pm 0,18$ & $33,51 \pm 0,97$ & $17,26 \pm 0,36$ & $5,23 \pm 0,33$ \\
\hline $\mathrm{Lj} \times \mathrm{AU} / L B W \times A U$ & $5,87 \pm 0,2$ & $39,64 \pm 1,52 * * *$ & $20,17 \pm 0,92$ & $6,65 \pm 0,93^{*}$ \\
\hline
\end{tabular}


4 lentelè. Genotipo ịtaka mèsos vandeningumui, vandens rišlumui, virimo nuostoliams ir kietumui

Table 4. The influence of genotype on meat wateriness, water binding capacity, cooling loss and tenderness

\begin{tabular}{|c|c|c|c|c|}
\hline $\begin{array}{l}\text { Veislè } \\
\text { Breed }\end{array}$ & $\begin{array}{c}\text { Vandeningumas \% } \\
\text { Waterness, \% }\end{array}$ & $\begin{array}{c}\text { Vandens rišlumas } \mathrm{mg} / \% \\
\text { Water binding capacity, } \mathrm{mg} / \%\end{array}$ & $\begin{array}{l}\text { Virimo nuostoliai \% } \\
\text { Cooking loss, \% }\end{array}$ & $\begin{array}{l}\text { Kietumas } \mathrm{kg} / \mathrm{cm}^{2} \\
\text { Tenderness, } \mathrm{kg} / \mathrm{cm}^{2}\end{array}$ \\
\hline $\mathrm{LJ} / L B W$ & $1,62 \pm 0,26$ & $57,66 \pm 2,02$ & $13,43 \pm 1,34$ & $1,79 \pm 0,23$ \\
\hline $\begin{array}{c}\mathrm{Lj} \times \mathrm{LI} \\
L B W \times L I\end{array}$ & $4,41 \pm 0,84^{\star *}$ & $56,26 \pm 1,51$ & $20,92 \pm 2,14^{\star *}$ & $3,07 \pm 0,41^{*}$ \\
\hline $\begin{array}{c}\mathrm{Lj} \times \mathrm{SI} \\
L B W \times S I\end{array}$ & $2,25 \pm 0,21$ & $54,04 \pm 3,83$ & $18,83 \pm 4,12$ & $1,68 \pm 0,29$ \\
\hline $\begin{array}{c}\mathrm{Lj} \times \check{\mathrm{S} A} \\
L B W \times C H\end{array}$ & $2,33 \pm 0,42$ & $56,78 \pm 0,9$ & $15,34 \pm 1,64$ & $1,86 \pm 0,19$ \\
\hline $\begin{array}{c}\mathrm{Lj} \times \mathrm{AN} \\
L B W \times A N\end{array}$ & $2,27 \pm 0,63$ & $54,03 \pm 2,3$ & $20,43 \pm 2,85^{\star}$ & $2,43 \pm 0,43$ \\
\hline $\begin{array}{c}\mathrm{Lj} \times \mathrm{AU} \\
L B W \times A U\end{array}$ & $5,51 \pm 0,88^{\star * *}$ & $57,15 \pm 1,62$ & $21,36 \pm 2,57^{\star *}$ & $2,47 \pm 0,47$ \\
\hline
\end{tabular}

Pastaba / Note: ${ }^{*}-p<0,05 ;{ }^{* *}-p<0,01 ;^{* * *}-p<0,001$ (LJ - kontrolinè grupé / control group).

pasižymėjo LJ $\times$ AU mišrūnų buliukų mèsa - 3,8 \% $(p<0,001)$, o LJ $\times$ LI mišrūnų buliukų - 2,7 \% $(p<0,01)$ vandeningesnè nei kontrolinès grynaveislių LJ buliukų grupès. Visų tirtujų mišrūnų buliukų grupių virimo nuostoliai buvo didesni, palyginti su kontrolinès grynaveislių LJ buliukų mèsos virimo nuostoliais: $\mathrm{LJ} \times \mathrm{AU} 7,93 \%(p<0,01), \mathrm{LJ} \times \mathrm{LI}$ $7,49 \%(p<0,01), \mathrm{LJ} \times \mathrm{AN} 7,0 \%(p<0,05)$. Kietesnè mèsa LJ $\times$ LI buliukų - 1,28 vieneto, arba 71,50\% $(p<0,05)$, palyginti su kontrolinès grynaveislių LJ buliukų mėsos kietumu. Analogiškus tyrimų rezultatus gavo ir G. Kalininas su kitais mokslininkais (2004).

Genotipo ịtaka mésos cheminei sudéčiai (5 lentelè) buvo skirtinga. Daugiausia sausųjų medžiagų nustatyta LJ × AN mišrūnų buliukų mėsoje - 1,4\% daugiau nei kontrolinės grynaveislių LJ buliukų mèsoje. Kitų tirtujų mišrūnų buliukų grupių sausųjų medžiagų kiekis mèsoje buvo panašus - LJ $\times$ LI
$1,3 \%, \mathrm{LJ} \times \check{\mathrm{S} A} 1,1 \%, \mathrm{LJ} \times \mathrm{AU} 0,5 \%$ ir LJ $\times \mathrm{SI} 0,3 \%$ daugiau nei LJ kontrolinės grupès buliukų. Tačiau duomenys buvo statistiškai nepatikimi.

Daugiausia baltymų buvo LJ $\times$ AN mišrūunų buliukų mèsoje - 3,7 \% $(p<0,01)$ daugiau nei kontrolinès grynaveislių LJ buliukų. Tyrimu duomenys parodé, kad daugiausia riebalų sukaupta LJ $\times$ AN mišrūnų buliukų mésoje - 1,24 \% $(p<0,01)$ daugiau nei kontrolinès grynaveislių LJ buliukų mėsoje. Pelenų kiekis visų tirtujų veislių mišrūnų buliukų grupių buvo mažesnis nei kontrolinès grynaveislių LJ buliukų $(p<0,001)$. Autoriai (Levakhin ir kt., 2008), atlikę bandymus, pastebéjo, kad mišrūnų mésa turi daugiau tarpraumeninių riebalų, o A. A. Kochetkovo (2007) duomenimis, mišrūnų mèsoje būna daugiau baltymų, geresnis jų pilnavertiškumas.

Iš dispersinès analizès duomenų matome (6 lentelè), kad veislè didžiausios įtakos turèjo skerdenos

5 lentelè. Genotipo ịtaka mèsos cheminei sudèčiai (musculus longissimus dorsi)

Table 5. The influence of genotype on the chemical composition of meat (musculus longissimus dorsi)

\begin{tabular}{|c|c|c|c|c|}
\hline \multirow{2}{*}{$\begin{array}{l}\text { Veislè } \\
\text { Breed }\end{array}$} & \multicolumn{4}{|c|}{ Cheminè sudètis \% / Chemical composition, \% } \\
\hline & S. M. / Dry substances & Baltymai / Proteins & Riebalai / Fats & Pelenai / Ash \\
\hline $\mathrm{LJ} / L B W$ & $24,8 \pm 0,48$ & $21,99 \pm 0,39$ & $1,56 \pm 0,21$ & $1,26 \pm 0,04$ \\
\hline $\mathrm{Lj} \times \mathrm{LI} / L B W \times L I$ & $26,11 \pm 0,41$ & $23,3 \pm 0,35$ & $1,68 \pm 0,24$ & $1,13 \pm 0,02^{* * *}$ \\
\hline $\mathrm{Lj} \times \mathrm{SI} / L B W \times S I$ & $25,15 \pm 0,67$ & $21,74 \pm 0,6$ & $2,46 \pm 0,54$ & $0,96 \pm 0,03^{* * *}$ \\
\hline $\mathrm{Lj} \times \check{\mathrm{S}} \mathrm{A} / L B W \times C H$ & $25,96 \pm 0,54$ & $22,72 \pm 0,55$ & $2,21 \pm 0,46$ & $1,03 \pm 0,04^{* * *}$ \\
\hline $\mathrm{Lj} \times \mathrm{AN} / L B W \times A N$ & $26,2 \pm 0,41$ & $25,76 \pm 0,35^{\star \star}$ & $2,8 \pm 0,47^{\star *}$ & $1,00 \pm 0,01^{\star * *}$ \\
\hline $\mathrm{Lj} \times \mathrm{AU} / L B W \times A U$ & $25,31 \pm 0,32$ & $22,76 \pm 0,28$ & $1,51 \pm 0,1$ & $1,04 \pm 0,05^{\star * *}$ \\
\hline
\end{tabular}

Pastaba / Note: ${ }^{\star}-p<0,05 ;{ }^{* *}-p<0,01 ;{ }^{* *}-p<0,001$ (LJ - kontrolinė grupé / control group) 
6 lentelè. Veislès ir buliaus ịtaka skerdenos masei ir išeigai \%

Table 6 . The influence of breed and bull on carcass mass and yield, \%

\begin{tabular}{c|c|c|c}
\hline $\begin{array}{c}\text { Požymis } \\
\text { Characteristic }\end{array}$ & $\begin{array}{c}\text { Priešskerdiminė gyvulio masė kg } \\
\text { Animall mass before slaughter, } \mathbf{k g}\end{array}$ & $\begin{array}{c}\text { Skerdenos masė kg } \\
\text { Carcass mass, } \mathbf{k g}\end{array}$ & $\begin{array}{c}\text { Skerdenos išeiga \% } \\
\text { Carcass yield, } \%\end{array}$ \\
\hline Veislè / Breed & $60,2^{* *}$ & $74,2^{* * *}$ & $67,5^{* * *}$ \\
\hline Bulius / Bull & $18,3^{*}$ & 8,6 & 5,1 \\
\hline
\end{tabular}

Pastaba / Note: ${ }^{\star}-p<0,05 ;^{* *}-p<0,01 ;^{* * *}-p<0,001$.

masei, skerdenos išeigai bei priešskerdiminei gyvulio masei $(p<0,001)$. Didžiausia buliaus įtaka buvo priešskerdiminei gyvulio masei $(p<0,05)$, o skerdenos masei bei išeigai - labai neryški ir statistiškai nepatikima.

Kaip matome iš dispersinès analizès duomenu (7 lentelè), veislès įtaka skerdenos klubo-šlaunies dalies morfologinei sudèčiai yra gana akivaizdi. Didžiausia veislès ịtaka buvo minkštųjų dalių masei, skerdenos klubo-šlaunies dalies masei ir kaulų masei $(p<0,001)$. Šiek tiek mažesnè - minkštųjų dalių išeigai $(p<0,05)$, buliaus ryškiausia ịta$\mathrm{ka}$ - išeigai $(p<0,05)$.

Dispersinès analizès duomenys parodè (8 lentelè) veislès ir buliaus ịtaką mèsos rūgštingumui ir spalvingumui. Galima teigti, kad veislè turèjo didesnę įtaką mésos šviesumui $L^{*}$ ir rausvumui $a^{*}$ $(\mathrm{p}<0,05)$.

Iš dispersinès analizès duomenu ( 9 lentelè) apie veislès ir buliaus ittaką mèsos vandeningumui, vandens rišlumui, virimo nuostoliams ir kietumui matome didelę veislès ittaką mèsos vandeningumui $(p<0,001)$ ir virimo nuostoliams $(p<0,05)$. Buliaus didesne įtaka mésos virimo nuostoliams $(p<0,05)$.

Dispersinès analizès duomenys apie veislès ir buliaus įtaką mėsos cheminei sudéčiai (10 lentelè) parodè, kad veislè turejo didelès itakos baltymu ir pelenų kiekiui $(p<0,001)$, bet mažiau lèmè riebalų kieki $(p<0,05)$. Buliaus ryškiausia ịtaka pelenų $(p<0,001)$ ir riebalų kiekiui $(p<0,05)$.

7 lentelè. Veislès ir buliaus ịtaka skerdenos klubo-šlaunies dalies morfologinei sudèčiai \%

Table 7. The influence of breed and bull on the morphological composition of the hock-femoral part of carcass, $\%$

\begin{tabular}{c|c|c|c|c|c}
\hline $\begin{array}{c}\text { Požymis } \\
\text { Characteristic }\end{array}$ & $\begin{array}{c}\text { Mase் } \\
\text { Mass }\end{array}$ & $\begin{array}{c}\text { Išeiga } \\
\text { Yield }\end{array}$ & $\begin{array}{c}\text { Kaulų mase் } \\
\text { Bone mass }\end{array}$ & $\begin{array}{c}\text { Minkštųjų dalių masė } \\
\text { Mass of soft tissues }\end{array}$ & $\begin{array}{c}\text { Minkštųjų dalių išeiga } \\
\text { Yield of soft tissues }\end{array}$ \\
\hline Veislè / Breed & $79,7^{\star * *}$ & $37,5^{* *}$ & $46,6^{* * *}$ & $81,5^{\star * *}$ & $33,3^{*}$ \\
\hline Bulius / Bull & 5,8 & $26,4^{*}$ & 14,1 & 5,3 & 9,7 \\
\hline
\end{tabular}

Pastaba / Note: ${ }^{\star}-p<0,05 ;{ }^{* *}-p<0,01 ;{ }^{* *}-p<0,001$.

8 lentelè. Veislès ir buliaus ịtaka mėsos rūgštingumui ir spalvingumui \%

Table 8. The influence of breed and bull on the acidity and colour of meat, \%

\begin{tabular}{c|c|c|c|c}
\hline \multirow{2}{*}{ Veiksnys / Characteristic } & \multirow{2}{*}{$\mathbf{p H}$} & \multicolumn{3}{|c}{ Spalvingumas / Colour } \\
\cline { 3 - 5 } & & $\mathbf{L}^{*}$ & $\mathbf{a}^{*}$ & $\mathbf{b}^{*}$ \\
\hline Veislè / Breed & 22,0 & $33,1^{*}$ & $25,4^{*}$ & 18,7 \\
\hline Bulius / Bull & 22,9 & 14,7 & 28,2 & 29,6 \\
\hline
\end{tabular}

Pastaba / Note: ${ }^{*}-p<0,05 ;{ }^{* *}-p<0,01 ;{ }^{* * *}-p<0,001$.

9 lentelè. Veislès ir buliaus ịtaka mėsos vandeningumui, vandens rišlumui, virimo nuostoliams ir kietumui \% Table 9. The influence of breed and bull on meat wateriness, water binding capacity, cooking loss and tenderness, $\%$

\begin{tabular}{c|c|c|c|c}
\hline $\begin{array}{c}\text { Veiksnys } \\
\text { Characteristic }\end{array}$ & $\begin{array}{c}\text { Vandeningumas } \\
\text { Wateriness }\end{array}$ & $\begin{array}{c}\text { Vandens rišlumas } \\
\text { Water binding capacity }\end{array}$ & $\begin{array}{c}\text { Virimo nuostoliai } \\
\text { Cooking loss }\end{array}$ & $\begin{array}{c}\text { Mèsos kietumas } \\
\text { Meat tenderness }\end{array}$ \\
\hline Veislè / Breed & $46,3^{* * *}$ & 7,5 & $25,7^{*}$ & 25,3 \\
\hline Bulius / Bull & 15,9 & 20,1 & $28,4^{*}$ & 18,7 \\
\hline
\end{tabular}

Pastaba / Note: ${ }^{*}-p<0,05 ;{ }^{* *}-p<0,01 ;{ }^{* * *}-p<0,001$. 
10 lentelè. Veislès ir buliaus ịtaka mèsos cheminei sudèčiai \%

Table 10. The influence of breed and bull on the chemical composition of meat, \%

\begin{tabular}{ccccccc}
\hline Veiksnys / Characteristic & S. M. / Dry substances & Baltymai / Proteins & Riebalai / Fats & Pelenai / Ash \\
\hline Veislè / Breed & 17,7 & $52,2^{* * *}$ & $24,2^{*}$ & $52,3^{* * *}$ \\
\hline Bulius / Bull & 12,2 & 6,0 & $35,3^{\star}$ & $41,3^{\star * *}$ \\
\hline
\end{tabular}

Pastaba / Note: ${ }^{\star}-p<0,05 ;{ }^{* *}-p<0,01 ;{ }^{* *}-p<0,001$.

Atlikus koreliacinę analizę nustatyta, kad gyvulio masé teigiamai $(r=0,881)$ koreliuoja su skerdenos mase ir jos išeiga, skerdenos klubošlaunies dalies mase, klubo-šlaunies dalies kaulų mase ir minkštụjų dalių mase $(p<0,01)$. Nustatyta vidutiniškai neigiama koreliacija tarp skerdenos klubo-šlaunies dalies masès, skerdenos klubošlaunies dalies kaulų masès ir minkštųjų dalių masès su mésos $\mathrm{pH}(-0,3 \geq r \leq-0,49 ; p<0,01)$. Skerdenos klubo-šlaunies dalies masè vidutiniškai teigiamai $(r=0,400$ ir $r=0,426)$ koreliavo su mésos šviesumu $L^{*}$ ir rausvumu $\mathrm{a}^{*}(p<0,01)$. Nustatyta stipri teigiama $(r=0,602)$ koreliacija tarp mèsos vandeningumo su skerdenos išeiga ir skerdenos klubo-šlaunies dalies mase $(p<0,01)$. Sausųjų medžiagų kiekis mèsoje koreliavo su mésos riebalais $r=0,422$ ir baltymais $r=0,703$ $(p<0,01)$.

\section{IŠVADOS}

1. Skirtingo genotipo 500 dienų amžiaus buliukų masė buvo nevienoda. Daugiausia svère $L J \times \check{S} A$ mišrūnai - 53,0 kg, arba 10,8 \% daugiau nei grynaveisliai LJ buliukai $(p<0,001)$. LJ $\times$ LI mišrūnai svère $36 \mathrm{~kg}$, arba 7,3\%, LJ $\times$ AU $18 \mathrm{~kg}$, arba 3,6\% $(p<0,001), \mathrm{LJ} \times \mathrm{AN}$ ir $\mathrm{LJ} \times \mathrm{SI}$ mišrūnai $11 \mathrm{~kg}$, arba 2,2 \% $(p<0,05)$ daugiau nei grynaveisliai LJ buliukai.

2. Visų veislių mišrūnai pasižymèjo didesne augimo sparta. Jų priesvoriai per parą 120-500 dienų laikotarpiu buvo 47-143 g, arba 4,9-14,9 \% didesni nei LJ buliukų.

3. Visų veislių mišrūnai $1 \mathrm{~kg}$ priesvorio sunaudojo 1,1-6,5 MJ/AE pašaro energijos, arba 1,5$8,2 \%$ mažiau nei LJ buliukai. Mažiausia pašarų priesvorio vienetui reikejjo $L J \times$ ŠA mišrūnams.

4. Visų veislių mišrūnų skerdenos išeiga buvo 3,2-5,4 \% didesnè nei LJ buliukų ( $p>0,05-$ $p<0,001)$. Didžiausia $-\mathrm{LJ} \times \mathrm{SI}$ veislès mišrūnų, jų buvo aukštesnè ir skerdenos raumeningumo kategorija.
5. Mišrūnų geriau išvystyti skerdenos klubošlaunies dalies raumenys, todèl jų didesnè minkštųjų dalių išeiga nei LJ buliukų iš šios skerdenos dalies.

6. Visų veislių mišrūnų, išskyrus $\mathrm{LJ} \times \mathrm{AN}$, mėsa buvo šviesesnè nei LJ buliukų ( $p>0,05<0,001)$. Kitų mėsos kokybès rodiklių skirtumai įvairavo priklausomai nuo veislès $(p>0,05<0,01)$. Baltymų kiekį mésoje 52,2 \% lèmè veislè ir $6 \%$ bulius, riebalų kieki - 24,2 \% veislè ir 35,3\% bulius.

7. Tyrimo duomenų dispersinè analizé parodé, kad skerdenos išeigą, mèsos spalvingumą $L^{*}$, vandeningumą ir baltymų kiekí daugiausia lèmé veislè. Kitiems rodikliams panašiai itakos turejo ir veisle, ir bulius. Mažiausia buliaus ịtaka nustatyta skerdenos išeigai, minkštụjų dalių išeigai iš klubošlaunies dalies, mėsos vandeningumui ir baltymų kiekiui mésoje.

Gauta 20151116 Priimta 20160609

\section{LITERATŪRA}

1. Babarinov I. E., Bugatov A. P. 2001. Myasnaay produktivnost' i kachestvo myasa bychkov chernopesnogo skota i nomesei ot skrechchivaniya s bykami myasnykh porod. Materialy mezhdunarodnoi nauchno-prakticheskoi konferentsii, posveshchennoi 100-letiyu so dnya rozhdeniya K. F. Akopyana. Orenburg. S. 244-249.

2. Daszkiewicz T., Wajda S., Kondratowicz J. 2005. Physico-chemical and sensory properties of meat from Black-and-White and Black-andWhite $\times$ Limousine heifers differing in intramuscular fat content. Animal Science. Vol. 23. P. 181-187.

3. Ekombetov K. T., Talochnina V. P. 2005. Myasnaya produktivnost' bychkov kholmogorskoi i gereforskoi pogod. Zootekhniya. No. 8. S. 21-22.

4. Gao Y., Zhang R., Hu X., Li N. 2007. Application of genomic technologies to the improvement of meat quality of farm animals. Animal Science. Vol. 77. P. 36-45.

5. Gnezdilova N., Kibkalo L. 2006. Osobenosti rasta i razvitiya chistoporodnykh i pomesnykh bychkov. Molochnoe i myasnoe skomovodstvo. No. 5. S.28-33. 
6. Grau R., Hamm R. 1956. Die Bestimmung des Wasserbindung des Fleisches mittels der Pressmethode. Fleischwirtschaft. P. 733-736.

7. Jukna Č., Jukna V., Šimkus A. 2003. Mineralinių medžiagu ir vitaminų ịtaka mėsos fizinėms savybėms. Veterinarija ir zootechnika. T. 23(45). P. 74-78.

8. Jukna Č., Jukna V. 1998. Prancūzų mėsinių veislių galvijų itaka Lietuvos galvijų mésos produkcijai. Žemés ùkio mokslai. Nr. 2. P. 90-93.

9. Jukna Č., Jukna V., Pečiulaitienè N. 2006. Lietuvos juodmargių bulių itaka palikuonių penejjimosi ir mėsinėms savybèms. Veterinarija ir zootechnika. T. 36(58). P. 27-29.

10. Jukna V., Jukna Č., Pečiulaitienè N., Kerinas E. 2009. Galvijų lyties ir amžiaus ịtaka skerdenų išeigai ir raumeningumo klasei. Veterinarija ir zootechnika. T. 46. P. 20-23.

11. Kjeldahl J. 1883. A new method for the determination of nitrogen in organic matter. Zeitschrift für Analytische Chemie. Vol. 22. P. 366.

12. Kochetkov A. A. 2007. Kachestvo myasa u chistoporodnykh i pomesnykh zhivotnykh. Zootekhniya. No. 11. S. 28-30.

13. Kalinin G., Dolgachev S. 2000. Viyanie tekhnologii otkorma i genotipa Bykovo na kachestbo myasa.

14. Kosilov V., Mirinenko S. 2004. Osobenosti rasta i myasnoi produktivnosti chistoporodnykh i pomesnykh bykov. Molochnoe i myasnoe skotovodstvo. No. 4. S. 4-5.

15. Levakhin V. I., Sirazetdinov F. Kh., Popov V. V., Salo A. V., Titov M. G., Akhmetova F. F. 2008. Effunktivnost' skreahchivaniya beztuzhestkogo skota s gerefordskim i limuzinskim pri proizvodstve govyadiny. Zootekhniya. No. 6. S. 18-19.

16. Ozluturk A., Tuzemen N., Yanar M., Esenbuga N., Dursun E. 2004. Fattening perfomance, car- cass traits and meat quality characteristics of calves sired by Chalolais, Simmental and Eastern Anatolian Red sires mated to Eastern Anatolian Red dams. Meat Science. Vol. 67. P. 463-470.

17. Renand G., Picard B., Touraille C., Berge P., Lepetit J. 2001. Relationships between muscle characteristics and meat quality traits of young Charolais bulls. Meat Science. Vol. 59. P. 49-60.

18. Stankevičius H. 2001. Skirtingų veislių kiaulių mèsos kokybès pokyčiai technologinio proceso metu. Maisto chemija ir technologija. T. 35. P. 132.

19. Stimbirys A., Jukna V. 2010. Lietuvoje auginamuc kiaulių veislių penèjimosi, skerdenos ir mèsos kokybès ivertinimas. Veterinarija ir zootechnika. T. 52. P. 73-78.

20. Shchukina T. N. 2008. Rost i razvitie pomesei cherno-pestrykh korov s bikami porod limuzin i shchapole. Zootekhniya. No. 3. S. 16-20.

21. Sudarev N. P., Sharkaev V. I. 2008. Izuchenie rasta i razvitiya sharalezkikh pomestei. Myasnaya industriya. S. 29-31.

22. Van Oeckel M. J., Warnants N., Boucqueė C. H. 1999. Comparison of different methods for measuring water holding capacity and juiciness of pork versus on-line screening methods. Meat Science. Vol. 51. P. 313-320.

23. Wajda S., Daszkiewicz T., Januškevičienė G., Dailidavičienė J. 2006. Fattening results and carcass quality of young bulls produced by mating Polish black-and-white cows to Charolaise and Simental sires. Veterinarija ir zootechnika. T. 33. P. 84-89.

24. Zelenov G. N. 2006. Osobenosti formirovaniya myasnoi produktivnosti u bychkov reznykh genotipo. Zootekhniya. No. 5. S. 26-28. 


\section{Audrius Korsukovas, Česlovas Jukna,} Vaidotas Prusevičius

THE INFLUENCE OF BEEF BULLS ON MEAT PRODUCTION AND QUALITY OF LITHUANIAN BLACK-AND-WHITE CATTLE

\section{Sum mary}

This article provides information about the influence of different bulls on the growth rate, feeding cost of gain, carcass yield, quality and morphological composition, and the physical properties and chemical composition of the meat of Lithuanian Black-and-White cattle. The following groups of offspring bulls of thoroughbred Lithuanian Black-and-White (LBW) cattle and crossbreeds of beef cattle bulls with Lithuanian Black-and-White cows were formed for the study: thoroughbred Lithuanian Black-and-White (LBW), Lithuanian Black-and-White $\times$ Limousine $(\mathrm{LBW} \times \mathrm{LI})$, Lithuanian Black-and-White $\times$ Simmental $(\mathrm{LBW} \times \mathrm{SI})$, Lithuanian Black-and-White $\times$ Charolais $(\mathrm{LBW} \times \mathrm{CH})$, Lithuanian Black-and-White $\times$ Angus $(\mathrm{LBW} \times \mathrm{AN})$, Lithuanian Blackand-White $\times$ Aubrac $(\mathrm{LBW} \times \mathrm{AU})$. There were $18-20$ bulls in each group. The groups consisted of offsprings of two bulls. The study was carried out with the bulls from 120 to 500 days of age. The biggest weight among 500 days bulls was discovered in the group of $\mathrm{LBW} \times \mathrm{CH}$ bulls. Their body mass was by $53 \mathrm{~kg}$ or 10.8 per cent bigger than that of the thoroughbred LBW individuals of the same age $(p<0.001)$. The greatest overweight was characteristic of the $\mathrm{LBW} \times \mathrm{CH}$ bulls. Their diurnal overweight was by $143 \mathrm{~g}$ or 14.9 per cent bigger as compared with that of the thoroughbred LBW bulls $(p<0.001)$. The lowest forage input was detected in the group of crossbred LBW $\times \mathrm{CH}$ bulls. It was by $6.5 \mathrm{MJ} /$ $\mathrm{ME}$ (megajaules/metabolism energy) or 8.4 per cent lower than that of the thoroughbred LBW bulls. The biggest carcass mass was found in the group of crossbred LBW $\times \mathrm{CH}$ bulls. Their carcass mass was by $51.5 \mathrm{~kg}$ or 19.0 per cent $(p<0.001)$ bigger, and the carcass mass of LBW $\times$ LI crossbred individuals was by $35.8 \mathrm{~kg}$ or 13.2 per cent $(p<0.01)$ bigger than that in the control group of LBW bulls. The biggest carcass yield was found in the group of LBW $\times$ SI crossbreeds, i. e. even by 5.4 per cent as compared with the thoroughbred LBW bulls $(p<0.001)$. The carcass yield in other crossbreed groups was the following: LBW $\times \mathrm{AU}$ $3.7 \%(p<0.001), \mathrm{LBW} \times \mathrm{CH} 3.2 \%(p<0.01)$ and LBW $\times \mathrm{AN}$ $3.5 \%(p<0.05)$ higher than in the control group of thoroughbred LBW bulls. The highest protein content was found in the meat of LBW $\times$ AN crossbreeds. The protein content in this group was by 3.7 per cent $(p<0.01)$ higher than in the meat of control thoroughbred LBW bulls. The data of dispersion analysis showed that the breed had the highest influence on the carcass mass, carcass yield and animal mass before slaughter $(p<0.001)$. The most significant impact of bull was on the animal mass before slaughter $(p<0.05)$, and the amount of ash $(p<0.001)$ and fat $(p<0.05)$.

Keywords: Lithuanian Black-and-White, carcass yield, meat quality, forage input 